\title{
PENGEMBANGAN PERANGKAT PEMBELAJARAN FISIKA BERORIENTASI PADA KREATIVITAS CALON GURU
}

\author{
Hairunnisyah Sahidu*, Gunawan, Joni Rokhmat, Satutik Rahayu \\ Program Studi Pendidikan Fisika, Universitas Mataram \\ *Email: hairunisyahsahidu@unram.ac.id
}

\begin{abstract}
Learning tools are an important part of learning. Innovative learning tools will help lecturers and students achieve the goals in learning. The purpose of this research is to produce an innovative learning tools oriented to the creativity of preservice physics teachers. The type of research is development research, using DDD-E model: decide, design, develop, and evaluate. Instruments used include physics concept test with multiple choice form, essay-type creativity test, activity observation sheet in Likert scale questionnaire. In this study also conducted empirical testing to measure the effectiveness of learning tools which developed to increase student creativity. The results show that the highest creativity improvement of the experimental class on verbal creativity.
\end{abstract}

Keywords : Physics learning tools, creativity

\section{PENDAHULUAN}

Kualitas pendidikan saat ini masih menjadi permasalahan mendasar dalam usaha perbaikan mutu sistem pendidikan nasional. Berbagai upaya telah dilakukan untuk meningkatkan kualitas pendidikan, mencakup semua komponen pendidikan seperti, kurikulum, peningkatan kualitas guru dan dosen, pengadaan buku ajar dan sarana belajar lainnya, pengembangan sistem pembelajaran, penyempurnaan sistem penilaian, penataan organisasi dan manajemen pendidikan. Mutu pendidikan ditentukan oleh berbagai faktor, salah satu diantaranya adalah proses belajar mengajar.

Peningkatan kualitas pendidikan fisika di sekolah ataupun di perguruan tinggi bisa dibenahi melalui peningkatan mutu pembelajaran fisika di perguruan tinggi, khususnya perguruan tinggi yang menyiapkan pendidik/tenaga kependidikan di bidang fisika. Beberapa ahli menyebutkan bahwa untuk meningkatkan mutu pembelajaran dapat dilakukan dengan upaya peningkatkan mutu perangkat pembelajarannya. Perangkat pembelajaran adalah sekumpulan sumber belajar yang memungkinkan dosen dan mahasiswa melakukan kegiatan pembelajaran. Penggunaan perangkatan pembelajaran yang baik, diharapkan dapat membantu terciptanya/terlaksananya pembelajaran yang baik pula, yang pada gilirannya akan meningkatkan keefektifan pembelajaran, berdaya saing.

Perangkat pembelajaran fisika yang akan digunakan dalam mempersiapkan calon guru fisika, perlu dipersiapkan sedemikian rupa sehingga keterlaksanaannya selain dapat meningkatkan penguasaan konsep fisika, juga dapat meningkatkan keterampilan berpikir mahasiswa fisika. Salah satu keterampilan berpikir yang dapat ditingkatkan adalah kreativitas. Nisrina et. al. (2016) mengungkapkan bahwa dengan menurunya tingkat penguasaan konsep siswa pada fisika, maka daya kreativitas mereka juga akan berkurang. Menurut Marisi (2007), masalah yang dihadapi dalam upaya pengembangan kreativitas antara lain disebabkan oleh rendahnya kemampuan yang dimiliki dosen dalam mengukur kreativitas mahasiswa dalam pembelajaran, 
dosen sesungguhnya belum paham tentang kreativitas seperti apa yang harus diukurnya dan bagaimana strateginya, selain itu lingkungan yang tidak kondusif serta belum tepatnya sistem penilaian yang berlaku akan menjadi penghambat perkembangan kreativitas mahasiswanya. Selain itu penggunaan perangkat pembelejaran seperti halnya model dan media pembelajaran yang tidak tepat dapat membatasi kemampuan peserta didik dalam menemukan dan mencoba hal-hal baru (Suranti et. al., 2016).

Kreativitas muncul karena adanya semangat dalam perhatian terhadap kegiatan atau pekerjaan yang sedang dilakukan, adanya kelancaran pemikiran dalam menghasilkan berbagai ide cemerlang, adanya kemampuan untuk mengeksperimen dengan melakukan pengujian-pengujian sehingga dapat menemukan sesuatu yang bermanfaat. Rawat et. al. (2012) menyatakan bahwa kreativitas merupakan tujuan utama pendidikan di seluruh dunia. Selain itu Wyse \& Ferrari (2015) mengungkapkan bahwa kreativitas dapat dikembangkan melalui proses pembelajaran dan hasilnya akan mencerminkan sesuatu yang baru dan bernilai.

Berangkat dari uraian tersebut, dalam penelitian ini dikembangkan sebuah perangkat pembelajaran fisika berorientasi pada kreativitas calon guru.

\section{METODE PENELITIAN}

Penelitian ini termasuk jenis penelitian dan pengembangan (Research and Development). Secara umum penelitian dilakukan dalam 4 tahapan, DDD-E, yaitu: Decide (tahap memutuskan), Design (tahap mendesain), Develop (tahap pengembangan), dan Evaluate (tahap mengevaluasi). Subjek penelitian ini adalah mahasiswa pada Program Studi Pendidikan
Fisika FKIP Universitas Mataram yang mengikuti beberapa matakuliah berbeda. Instrumen yang digunakan meliputi tes penguasaan konsep fisika, berbentuk pilihan ganda, tes kreativitas berbentuk essay pada aspek verbal, figural, maupun numerik, lembar observasi kegiatan dalam angket skala Likert, untuk mengetahui tanggapan mahasiswa calon guru dan dosen terhadap pembelajaran yang telah dilaksanakan.

Teknik pengolahan data untuk menjawab setiap pertanyaan penelitian disesuaikan dengan jenis dan karakteristik datanya. Untuk menguji tingkat signifikasi perbedaan peningkatan kemampuan kreativitas mahasiswa fisika dilakukan dengan menghitung perbedaan rerata skor $\mathrm{N}$-gain pada kedua kelas menggunakan uji statistik parametrik.

\section{HASIL DAN PEMBAHASAN}

Kreativitas merupakan proses mental yang melibatkan generasi ide-ide baru atau konsep, atau asosiasi baru antara ide atau konsep yang ada. Dari sudut pandang ilmiah produk pemikiran kreatif biasanya dianggap memiliki kedua orisinalitas dan kesesuaian (Jackson et. al., 2012). Penguasaan konsep yang kuat sangat dibutuhkan dalam menciptakan gagasan baru yang kreatif untuk digunakan dalam menciptakan ide baru.

Kreativitas dalam dunia pendidikan meliputi bagaimana mahasiswa mampu berproses secara kreatif, merumuskan dan memecahkan suatu masalah yang tentunya melibatkan pemikiran kognitif (N. Jausovec \& K. Jausovec, 2011). Selain itu Kampylis \& Valtanen (2010) mengungkapkan bahwa kreativitas dalam konteksnya mencakup kemampuan kunci individu dalam proses kreatif yang menciptakan suatu produk baru, asli, tidak konvensional, berharga, berguna. 
Berdasarkan pada pemahaman tersebut, pendidikan membutuhkan proses pembelajaran yang kreatif dan inovatif untuk menciptakan kemampuan mahasiswa yang diinginkan. Salah satu faktor penting dalam pembelajaran kreatif adalah perangkat pembelajarannya. Bentuk RPP, media ajar dan instrumen yang berpaku hanya pada bentuk penyampaian materi ajar hanya akan membuat proses pembelajaran membosankan dan tidak kreatif. Oleh karena itu, bentuk perangkat pembelajaran yang dibuat merupakan bentuk perangkat yang berfokus pada indikator-indikator kreativitas yang mendukung kemampuan berpikir tingkat tinggi. Perangkat pembelajaran ini terdiri dari bentuk-bentuk yang disesuaikan dengan karakteristik yang kreatif. Bentuk tersebut berfokus pada tiga jenis kreativitas yang akan dilihat peningkatannya yakni verbal, figural, dan numerik. Setiap bentuk kreativitas ini akan didukung oleh bentuk perangkat yang sesuai.

Perangkat pembelajaran yang dibuat memiliki empat indikator kreativitas berupa: fluency, flexibility, elaboration dan originality yang tentunya akan berbeda bentuk dan struktur di setiap perangkat yang dibuat. RPP yang dibuat berisi tentang langkah pembelajaran kreatif, hal ini disesuaikan dengan jenis kreativitas yang akan diukur dengan metode mengajar yang akan digunakan. Instrument yang dibuat disesuaikan dengan jenis-jenis soal kreativitas verbal, figural, dan numerik yang juga harus sesuai dengan keempat indikator kreativitas. Perangkat pembelajaran yang paling penting dalam proses kreatif adalah lembar kerja dan media pendukung yang digunakan. Bentuk perangkat lembar kerja dibuat dalam bentuk yang tidak penuh dengan narasi, namun mengandung unsur kreativitas verbal, terdapat gambar yang mendukung figuralnya, serta bentuk-bentuk persamaan yang sesuai dengan kreativitas numerik. Media yang digunakan harus sesuai, kreatif, dan mampu memotivasi dalam menciptakan ide-ide kreatif. Fisika membutuhkan perangkat yang tepat untuk mengungkapkan setiap konsep yang ada dan mengelaborasinya dengan baik. Perangkat pembelajaran fisika yang disusun berdasarkan tiga jenis kreativitas (verbal, figural, dan numerik) mampu menghasilkan kemampuan kreatif yang sesuai untuk fisika dan pembelajarannya.

Kreativitas dapat membantu dalam melakukan segala hal dengan lebih baik, baik hal terkait karier maupun kehidupan secara keseluruhan yang dimunculkan dari kebiasaan. Menurut Ekasari et. al. (2016) kreativitas merupakan kemampuan seseorang untuk menghasilkan suatu produk yang baru ataupun kombinasi dari hal-hal yang sudah ada sebelumnya, yang berguna, serta dapat dimengerti. Tugas seorang pendidik sebagai pembentuk sumber daya manusia, harus mampu membentuk kreativitas melalui perangkat pembelajaran yang digunakan. Perangkat pembelajaran kreativitas mampu mempermudah seorang pendidik dalam proses fasilitasi pembelajaran. Dengan perangkat pembelajaran kreativitas, seorang pendidik dapat dengan mudah menyampaikan materi hanya dengan melihat perangkatnya tanpa harus banyak berpikir dan mengingat. Dalam perencanaan pembelajaran, dilakukan penyusunan skenario pembelajaran yang tertuang dalam RPP, silabus, perangkat penilaian, lembar kerja, sumber dan media belajar yang mampu meningkatkan kreativitas peserta didik. Modifikasi model, media, dan instrumen penilaian tersebut mampu menumbuhkan kreativitas peserta didik ke arah yang lebih 
positif. Selain itu, salah satu tujuan dari perangkat pembelajaran adalah untuk memenuhi keberhasilan seorang pendidik dalam pembelajaran. Perangkat pembelajaran yang telah dikembangkan mampu meningkatkan kreativitas peserta didik. Hal ini ditunjukkan oleh adanya peningkatan terhadap hasil tes kreativitas peserta didik.

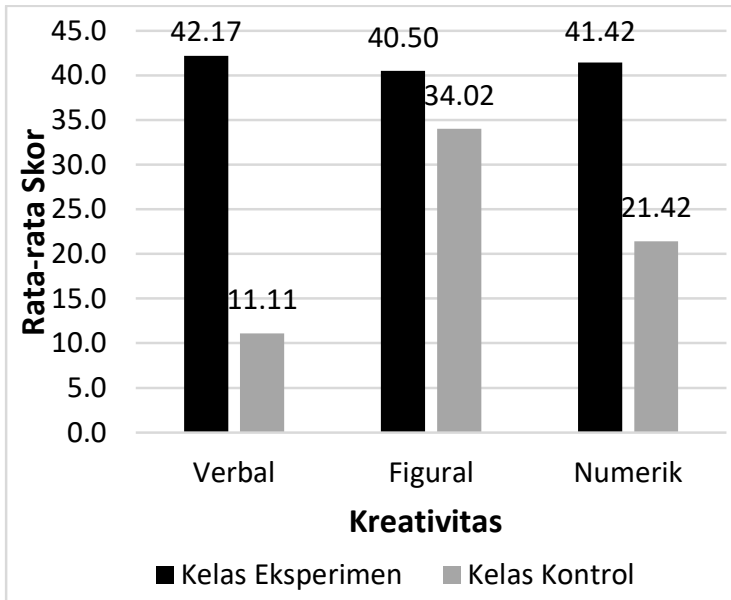

Gambar 1. Rata-rata Skor Kreativitas Verbal, Figural, dan Numerik Mahasiswa

Data pada Gambar 1 tersebut menunjukkan bahwa kemampuan kreativitas mahasiswa kelas eksperimen lebih tinggi dibandingkan dengan kelas kontrol di setiap jenis kreativitas. Hal ini membuktikan bahwa perangkat pembelajaran yang digunakan efektif dan mampu menciptakan kondisi yang sesuai dengan kebutuhan mahasiswa. Setiap bentuk perangkat pembelajaran yang diberikan disesuaikan dengan setiap jenis kreativitas yang ada, sehingga mampu meningkatkan kreativitas mahasiswa baik verbal, figural, maupun numeriknya. Hal ini sejalan dengan Cropley (2012) yang menyatakan bahwa kreativitas membutuhkan bentuk-bentuk perangkat yang mendukung dan sesuai untuk perkembangannya. Pengembangan perangkat pembelajaran yang kreatif menunjang kemampuan mahasiswa dalam menyampaikan ide-ide yang cukup banyak dan variatif. Selain itu, dengan adanya bentuk instrumen yang mendorong mahasiswa untuk memberikan bentuk jawaban yang berbeda-beda mampu menciptakan dan meningkatkan kreativitas verbal mereka. Hal ini dibuktikan oleh data pada Gambar 1 untuk aspek kreativitas verbal yang menunjukkan bahwa mahasiswa pada kelas eksperimen memiliki kreativitas verbal yang paling tinggi dengan skor $42,17 \%$ dibanding kreativitas numerik dan figural. Hal ini berarti bahwa dengan menerapkan perangkat pembelajaran kreatif, calon guru lebih mampu berpikir secara divergen untuk mengkombinasikan ide secara verbal terhadap suatu persoalan yang tercermin dari kelancaran, kelenturan dan orisinilitas. Dalam penelitian Preckel et al (2006) ditemukan adanya korelasi positif antara kecerdasan dengan kreativitas, dengan korelasi terkuat ada pada kreativitas verbal. Selain itu Gunawan et. al. (2017) mengungkapkan bahwa perangkat pembelajaran kreatif dengan model project based learning berbantuan media virtual dapat meningkatkan kreativitas siswa, dengan peningkatan kreativitas verbal lebih tinggi dibandingkan kreativitas figural.

Perangkat pembelajaran tidak hanya berfokus pada kreativitas verbal saja. Kreativitas figural merupakan salah satu jenis kreativitas yang indikatornya sudah disesuaikan di setiap bentuk perangkat yang digunakan. Perangkat tersebut berhasil meningkatkan kreativitas figural mahasiswa yang ditunjukan dari skor yang dimiliki oleh kelas eksperimen pada sub kreativitas figural yang lebih tinggi dibandingkan dengan kelas kontrol. Dengan adanya perangkat yang menyajikan bentuk-bentuk figural yang sesuai dengan konsep yang ada, menjadikan mahasiswa tertarik untuk memahami dan 
menganalisis sehingga timbul ide-ide kreatif. Selain ini mahasiswa diminta untuk menyampaikan ide dan solusi dalam bentuk figural dan menginterpretasikannya.

Fisika merupakan materi pembelajaran yang sebagian besar penyelesaiannya membutuhkan persamaan. Oleh karena itu, kemampuan kreativitas numerik sangat dibutukan dalam menyelesaikan permasalahan tersebut. Perangkat pembelajaran kreatif yang disusun telah disesuaikan sehingga mampu meningkatkan kreativitas numerik mahasiswa. Hal ini dibuktikan oleh data pada Gambar 1 untuk sub kreativitas numerik. Kemampuan mahasiswa kelas eksperimen lebih tinggi dibandingkan dengan kelas kontrol pada kreativitas numeriknya karena didukung oleh perangkat pembelajaran yang sesuai. Mahasiswa kelas eksperimen lebih mampu mengkolaborasikan setiap persamaan yang ada sehingga mampu menciptakan lebih dari satu solusi yang tepat untuk sebuah permasalahan yang diberikan.

Kreativitas merupakan kemampuan tingkat tinggi yang dibutuhkan dalam pendidikan abad 21. Untuk membentuk kreativitas pada diri setiap mahasiswa, dibutuhkan perangkat pembelajaran yang sesuai dan efektif. Dengan adanya perangkat pembelajaran yang kreatif, kemampuan mahasiswa dalam menciptakan ide-ide kreatif mampu meningkat. Hal ini dibuktikan oleh data pada Gambar 2.

Data pada Gambar 2 menunjukkan bahwa hasil tes awal mahasiswa kelas eksperimen lebih rendah daripada mahasiswa kelas kontrol. Skor rata-rata yang dimiliki kelas eksperimen dan kelas kontrol masih tergolong rendah. Hal ini dikarenakan mahasiswa belum menerima pembelajaran dan hanya menggunakan pengalaman belajar mereka sebelumnya. Tes akhir yang diberikan pada kedua kelas setelah perlakuan menunjukkan hasil bahwa kelas eksperimen memiliki skor rata-rata yang lebih tinggi secara signifikan daripada kelas kontrol.

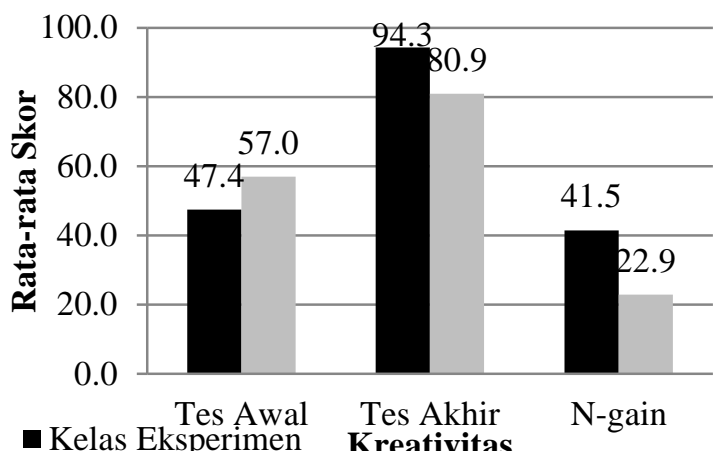

Gambar 2. Perbandingan Skor Tes Awal, Tes akhir dan Ngain Kreativitas Kedua kelas

Perbedaan tersebut menunjukkan bahwa perlakuan yang diberikan dengan menggunakan perangkat kreativitas memberi dampak positif. Selain itu, perbandingan hasil uji $\mathrm{N}$-gain yang dilakukan untuk mengetahui perbedaan peningkatan kedua kelas juga menunjukkan bahwa mahasiswa kelas eksperimen memiliki peningkatan yang lebih tinggi dibandingkan kelas kontrol. Mahasiswa kelas eksperimen mengalami peningkatan kreativitas yang tergolong dalam kategori sedang, sedangkan mahasiswa kelas kontrol memiliki peningkatan yang tergolong dalam kategori rendah.

\section{PENUTUP}

Berdasarkan hasil penelitian dan interpretasinya, dapat disimpulkan bahwa perangkat pembelajaran yang dikembangkan dapat meningkatkan kreativitas mahasiswa. Peningkatan kreativitas tertinggi kelas eksperimen pada kreativitas verbal. Meskipun demikian, peningkatan pada kedua kelas masih perlu ditingkatkan. Perangkat yang dikembangkan 
berada pada kategori baik, dan dapat digunakan untuk mendukung pembelajaran fisika berorientasi pada kreativitas mahasiswa.

Adapun beberapa hal yang dapat disarankan, yaitu perlunya pengaturan waktu dengan lebih efektif sehingga tahapan kegiatan yang direncanakan dapat berjalan sesuai target. Penggunaan dan pemilihan media pendukung pembelajaran sangat diperlukan untuk mendukung perangkat pembelajaran yang dikembangkan. Perlu penelitian lebih lanjut, khususnya pada tahapan yang mana dalam pembelajaran yang dominan membantu peningkatan kreativitas mahasiswa, serta perbandingan kreativitas mahasiswa berdasarkan gender maupun dengan gaya belajar berbeda.

\section{REFERENSI}

Cropley, A. (2012). Creativity and education: An Australian perspective. IJCPS-International Journal of Creativity and Problem Solving, 22(1), 9.

Ekasari, R. R., Gunawan, G., \& Sahidu, H. 2016. Pengaruh Model Pembelajaran Langsung Berbantuan Media Laboratorium Terhadap Kreatifitas Fisika Siswa SMA. Jurnal Pendidikan Fisika dan Teknologi, 2(3), 106-110.

Gunawan, G., Sahidu, H., Harjono, A., \& Suranti, N. M. Y. The Effect of Project Based Learning with Virtual Media Assistance on Student's Creativity in Physics. Cakrawala Pendidikan, (2).

Jackson, L. A., Witt, E. A., Games, A. I., Fitzgerald, H. E., von Eye, A., \& Zhao, Y. 2012. "Information Technology Use and Creativity: Findings from The Children and Technology Project". Computers in Human Behavior, 28(2), 370-376.

Jausovec, N., \& Jausovec, K. (2011). Brain, creativity and education. The open education journal, 4(1).
Kampylis, P. G., \& Valtanen, J. 2010. "Redefining Creativity - Analyzing Definitions, Collocations, and Consequences". Journal of Creative Behavior, 44 (3), 191-214.

Marisi, A. K. 2007. "Efektivitas Model Pengukuran Kreativitas dalam Pembelajaran Hemisphere Kanas (HK) untuk Meningkatkan Kreativitas Siswa Kelas V dalam Mata Pelajaran IPA di Sekolah Dasar". Jurnal Penelitian dan Evaluasi Pendidikan, 10(2), 169-190.

Nisrina, N., Gunawan, G., \& Harjono, A. (2016). Pembelajaran Kooperatif dengan Media Virtual untuk Peningkatan Penguasaan Konsep Fluida Statis Siswa. Jurnal Pendidikan Fisika dan Teknologi, 2(2), 66-72.

Preckel, F., Holling, H., \& Wiese, M. 2006. "Relationship of Intelligence and Creativity in Gifted and Non-Gifted Students: An Investigation Of Threshold Theory". Personality and individual differences, 40(1),159-170.

Rawat, K. J., Qazi, W., \& Hamid, S. (2012). Creativity and education. Academic Research International, 2(2), 264.

Suranti, N. M. Y., Gunawan, G., \& Sahidu, H. (2016). Pengaruh Model Project Based Learning Berbantuan Media Virtual Terhadap Penguasaan Konsep Peserta didik pada Materi Alat-alat Optik. Jurnal Pendidikan Fisika dan Teknologi, 2(2), 73-79

Wyse, D., \& Ferrari, A. (2015). Creativity and education: Comparing the national curricula of the states of the European Union and the United Kingdom. British Educational Research Journal, 41(1), 30-47. 